\title{
Giant dermoid cyst of ovary in postmenopausal woman: a case report
}

\section{Seetesh Ghose*, Chandana G., Setu Rathod, Lopamudra B. John}

Department of Obstetrics and Gynecology, Mahatma Gandhi Medical College and Research Institute. Pondicherry, Puducherrry, India

Received: 12 May 2017

Accepted: 10 June 2017

\section{* Correspondence:}

Dr. Seetesh Ghose,

E-mail: seetesh@mgmcri.ac.in

Copyright: (c) the author(s), publisher and licensee Medip Academy. This is an open-access article distributed under the terms of the Creative Commons Attribution Non-Commercial License, which permits unrestricted non-commercial use, distribution, and reproduction in any medium, provided the original work is properly cited.

\section{ABSTRACT}

A 49 year, miltipara, post-menopausal woman complains of pain abdomen and breathlessness for one week. On abdominal examination, there was a firm mass. MRI showed multi-loculated cystic lesion suggestive of ovarian dermoid cyst. Patient underwent TAH and BSO.

Keywords: Dermoid, Menopause woman

\section{INTRODUCTION}

The most probable ovarian tissue from which neoplasm arises are: surface epithelium, sex cord and germ cell. ${ }^{1}$ Benign cystic teratoma comprises of $32 \%$ of all ovarian tumors. $^{2}$ About $43-70 \%$ are found and diagnosed in reproductive years. Highest frequency is noticed during adolescence. $^{3}$ The peak incidence is observed between 15-19 years. ${ }^{4} 5-20 \%$ of cystic teratoma are found in postmenopausal women. ${ }^{5}$ However, occurrence of benign cystic teratoma is not uncommon in postmenopausal women.

\section{CASE REPORT}

Mrs. X, 49yrs, P3L3, post-menopausal for 21/2 years, complain of pain abdomen and breathlessness for one week. Pain was of insidious onset, constant, dull aching. There was no associated co-morbidity. On examination, she was found to have BMI $-28 \mathrm{~kg} / \mathrm{m}^{2}$, pallor ++ . There was no lymphadenopathy or edema. On abdominal examination, there was a mass extending from lower epigastric region to hypogastrium encroaching the right and left iliac region with ill-defined margins, firm in consistency, fixed, lower border not felt. There was a midline vertical LSCS scar. There was no free fluid. Speculum examination revealed normal vagina and cervix. Uterine size could not be elicited by bimanual examination. Fornixes were free. On investigation $\mathrm{Hb} \%$ was $6.7 \mathrm{~g} \%$, FBS-78 mgm $\%$, PPBS- $108 \mathrm{mgm} \%$, uera- 11 mgm $\%$, creatinine-0.6 mgm\%, LFT-normal, CA125108.2IU, CEA-2.7, LDH-497.

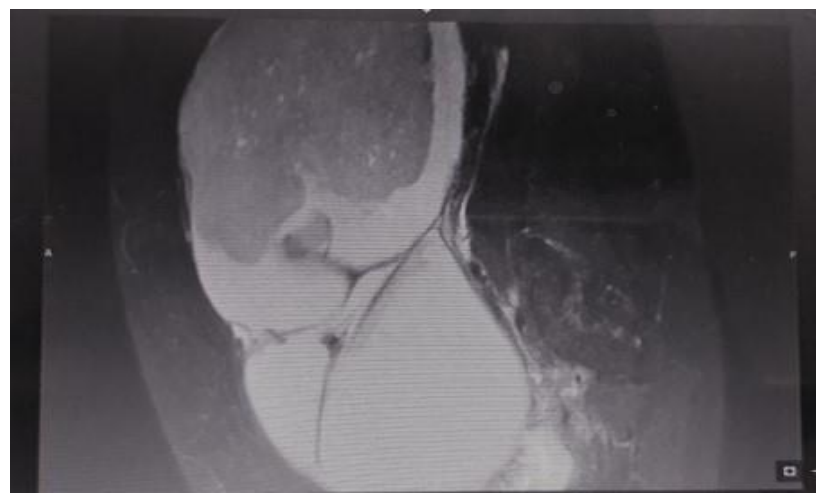

Figure 1: MRI showed multi-loculated cystic lesion.

Ultrasound of abdomen and pelvis revealed an ill-defined cystic lesion with normal right ovary but left ovary could 
not be separately visualized and no free fluid. MRI showed multi-loculated cystic lesion $(31.5 \times 22 \times 12 \mathrm{~cm})$ arising from pelvis with extension up to mid abdomen and fatty components within suggestive of left ovary dermoid cyst (Figure 1).

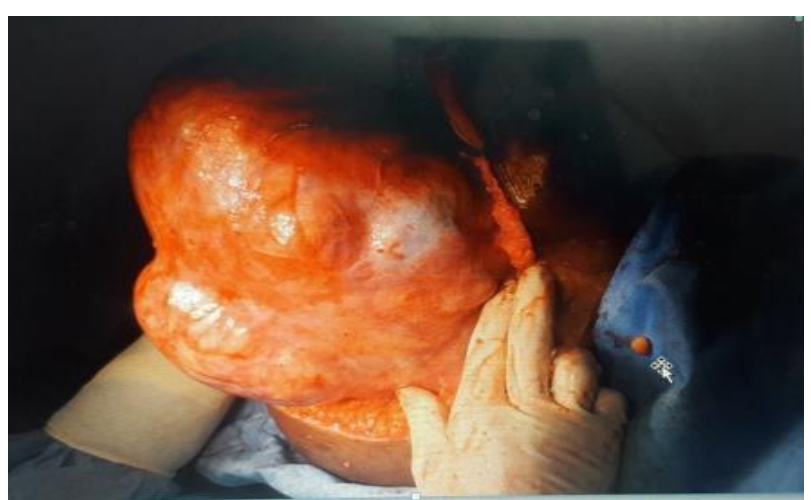

Figure 2: Left ovary dermoid cyst.

Minimal free fluid was also noticed in pelvis. Laparotomy was planned for her. On laparotomy, it was a left ovary dermoid cyst of $30 \mathrm{X} 20 \mathrm{X} 10 \mathrm{~cm}$ (Figure 2) with flimsy adhesions. Patient underwent TAH and BSO. Cut section showed teeth, hairs and plenty sebaceous materials. (Figure 3) Her postoperative period was uneventful. Histopathology confirmed as benign cystic teratoma.

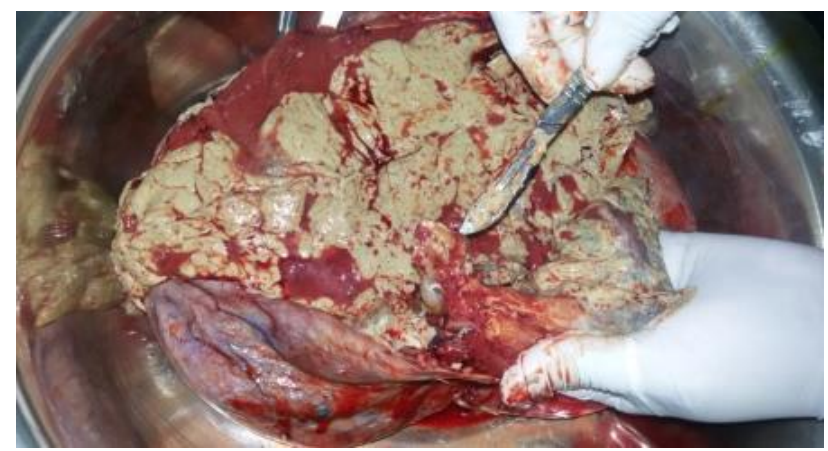

Figure 3: Cut section showed teeth, hairs and plenty sebaceous material.

\section{DISCUSSION}

Although benign cystic teratoma is the tumour of reproductive age, Ping et al reported a mature cystic teratoma of the ovary in a 16-yr old female and Lucksom et al reported a case of dermoid cyst of ovary in a 47 yrs old woman with malignant transformation. ${ }^{6,7}$ Patel et al reported a case of pregnancy with benign cystic teratoma in a 25 yrs woman. ${ }^{8}$ Size of these tumors varies from 0.5 -
$40 \mathrm{~cm}$. The significance of our case is occurrence of a huge cystic teratoma in postmenopausal age.

\section{CONCLUSION}

Although benign cystic teratoma is common in reproductive age, can occur in postmenopausal age group as well.

\section{ACKNOWLEDGMENTS}

Authors would like to thank department of radiology for helping us in arising the diagnosis of benign teratoma

\section{Funding: No funding sources \\ Conflict of interest: None declared \\ Ethical approval: Not required}

\section{REFERENCES}

1. Fattaneh AT, Peter D. WHO classification of tumors of the breast and female genital organs. Lyon France; 2002:114-5.

2. Russel P, Painter DM. The pathological assessment of ovarian neoplasms: The germ cell tumors. Pathology. 1982;14:47-72.

3. Shalev C, Bustan M, Romeno S. Laparoscopic resection of ovarian benign cystic teratomas: Experience with 84 cases. Hum Reprod. 1998;13:1810-2.

4. Wei F, Jiang Z. Yan C. Analysis of 20 mature ovarian cystic teratomas cases in postmenopausal women. Chin Med J (Engl). 2001;114:137-8.

5. Bal A, Mohan H, Sunitha BS, Sehgal A, Malignant transformation in mature cystic teratoma of the ovary: report of five cases and review of the literature. Arch Gynecol Obstet. 2007;275:179-82.

6. Ping T, Solaima S, Ellen K. Mature Cystic Teratoma of the Ovary Associated with Complete Colonic Wall and Mucinous Cystadenoma. Annals of Clinical and Laboratory Science. 2003;33(4):465-70.

7. Lucksom PG, Sebastian N, Pradhan D, Ritu R Malignant transformation of ovarian dermoid: a rare case. Int J Reprod Contracept Obstet Gynnecol. 2013;2(4):698-700

8. Patel MS, Shah AC, Pandya MJ, Thakkar JH. Pregnancy with Dermoid Cyst. Gujarat Medic J. 2015;70(1):95.

Cite this article as: Ghose $\mathrm{S}$, Chandana $\mathrm{G}$, Rathod $\mathrm{S}$, Lopamudra BJ. Giant dermoid cyst of ovary in postmenopausal woman: a case report. Int J Reprod Contracept Obstet Gynecol 2017;6:3195-6. 